\title{
Studies on Drug Delivery Efficacy of Silver Nanoparticles Synthesized using Human Serum Albumin as Tamoxifen Carriers in MCF-7 Cell Line
}

\author{
V. Pradeepa ${ }^{1}$, T. Sriram ${ }^{2}$, M. Sujatha ${ }^{3}$ \\ ${ }^{1}$ Department of Biotechnology, K.S.G College of Arts and Science, Coimbatore, Tamil Nadu, India \\ ${ }^{2,3}$ Department of Biotechnology, Sri Kaliswari College of Arts and Science, Sivakasi, Tamil Nadu, India
}

\begin{abstract}
Tamoxifen (Tam) has a broad spectrum of anticancer activity, but is limited in clinical application. The aim of this study was to explore the smart pH-responsive drug delivery system based on Human Serum Albumin (HSA) reduced Silver nanoparticles (AgNps)for its potential in enabling more intelligent controlled release and enhancing chemotherapeutic efficiency of tamoxifen. Tamoxifen was loaded onto HSA reduced AgNps by forming complexes and Tamoxifen was released from the drug delivery system much more rapidly at $\mathrm{pH} 4.0$ and 6.0 than at $\mathrm{pH}$ 7.4, which is a desirable characteristic for tumor targeted drug delivery. Tamoxifen loaded HSA reduced AgNps induced remarkable improvement in anticancer activity a demonstrated by MTT assay and AO/EtBr staining and the results indicated that the drug loaded nanoparticles could act as an efficient drug delivery system which import Tamoxifen into target cancer cells.
\end{abstract}

Keywords: Tamoxifen, Human Serum Albumin, Silver nanoparticles, Cancer, MCF-7

\section{Introduction}

Nanotechnology is now frequently used for various applications in fibre and textiles, agriculture, electronics, forensic science, space and medical therapeutics [1]. Biodegradable nanoparticles are frequently used to improve the therapeutic value of various water soluble/insoluble medicinal drugs and bioactive molecules by improving bioavailability, solubility and retention time [2]. Theses nanoparticle- drug formulation reduces the patient expenses, and risks of toxicity [3]. Nanoencapsulation of medicinal drugs (Nanomedicine) increases drug efficacy, specificity, tolerability and therapeutic index of corresponding drugs [4]. These nanomedicines have many advantages in the protection of premature degradation and interaction with the biological environment, enhancement of absorption in to a selected tissue, bioavailability, retention time and improvement of intracellular penetration [5]. Several disease related drugs/bioactive molecules are successfully encapsulated to improve bioavailability, bioactivity and control delivery [6].

Tamoxifen is a commonly used anti-cancer drug. It is most often used against breast cancer, carcinomas, osteosarcoma and soft tissue sarcoma. The effectiveness of tamoxifen in treating various types of cancers is greatly limited by the serious side effects caused by the drug. The initial side effects caused as a result of tamoxifen administration include less serious symptoms, such as nausea, vomiting, myelo suppression and arrhythmia, which are usually reversible [7]. However, tamoxifen associated cardiomyopathy and congestive heart failure have raised great concern among health practitioners [8]. A widely researched approach of increasing the efficacy, while lowering the deleterious side effects caused by anti cancer agents such as tamoxifen, is of developing nanoparticlesbased drug delivery systems [9]. The endogenous Human Serum Albumin (HSA) serves as a suitable material for nanoparticles formation as albumin is naturally found in the blood and is thus easily degraded, nontoxic and non immunogenic [10]. Albumin is an acidic protein and remains stable between $\mathrm{pH}$ range 4-9 and temperatures up to $60^{\circ} \mathrm{C}$. Albumin-based nanoparticles delivery systems are easily accumulated in tumor tissue due to the enhanced permeability and retention (EPR) effect [11].

Metallic nanoparticles have fascinated scientists for over a century and are now heavily utilized in biomedical sciences and engineering. Silver nanoparticles (AgNps) have emerged as an arch product in the field of nanotechnology [12]. AgNps have become efficient vehicles to store and deliver medicines. They are used for the controlled release of drugs and albumin-drug complexed, where Nanoparticles acts as a carrier of drugs and liberate them on selective basis. They can be used a magic bullets" that go directly to cells of a particular tissue [13].

In view of these developments, the aim of this paper is to explore a novel Tamoxifen delivery system based on AgNps synthesized using HSA that is chemically stable, environmentally friendly and non-cytotoxic. This type of Tamoxifen delivery system could provide simple and easy way to enable intelligently controlled release of drug and enhance its chemotherapeutic efficiency. To be the best of the authors' knowledge, no study has been carried out on AgNps synthesized using HSA for stimuli sensitive drug delivery system and is investigated here for the first time. In this study Tamoxifen was loaded on AgNps synthesized using HSA to construct drug loaded Nanoparticles as a drug delivery system. Loading efficiency and influence of $\mathrm{pH}$ value on drug release behavior were investigated. Additionally, tumor cellular uptake and cytotoxicity were evaluated in MCF-7 breast cancer cells. 


\section{International Journal of Science and Research (IJSR) \\ ISSN (Online): 2319-7064}

Index Copernicus Value (2015): 78.96 | Impact Factor (2015): 6.391

\section{Materials and methods}

$\mathrm{AgNO}_{3}(99.98 \%)$ was used as a silver precursor, and was provided by Merk (Darmstadt, Germany). $\mathrm{HNO}_{3}(70 \%)$, Human Serum Albumin (HSA) and HCL (37\%) were obtained from Sigma-Aldrich (St Lois, MO). The human breast cancer cell line (MCF7) was procured from National centre for Cell Science (NCCS, Pune). All the reagents in this effort were analytical grade and were used as received without further purification. All solution were freshly prepared using double distilled water and kept in a dark to avoid any photochemical reactions. All glass wares used in experimental procedures were cleaned in a fresh solution of $\mathrm{HNO}_{3} / \mathrm{HCl}(3: 1, \mathrm{v} / \mathrm{v})$, washed thoroughly with double distilled water and dried before use

\section{Synthesis of Silver Nanoparticles}

Silver Nano particles were prepared by wet chemical synthesis. An albumin solution was prepared dissolving $0.1 \mathrm{gms}$ of HSA in $30 \mathrm{ml}$ of deionized water. The $\mathrm{AgNO}_{3}$ solution was prepared dissolving $0.05 \mathrm{gms}$ of $\mathrm{AgNO}_{3}$ in 10 $\mathrm{ml}$ of deionized water. In the HSA solution, $\mathrm{AgNO}_{3}$ solution was added while stirring on a magnetic stirrer and after 5 minutes, ammonium hydroxide was added drop wise to maintain the $\mathrm{pH}$. It was stirred further for 15 minutes, and to let the solution settle down for 24 hours. The silver nano particles thus formed were isolated by filtration and washed with a minimum of amount of ethanol.

\section{Preparation of Tamoxifen-loaded HSA reduced AgNps}

Tamoxifen loaded nanoparticles were prepared by solvent evaporation and emulsification cross linking method. For the preparation of tamoxifen-loaded HSA reduced AgNPs, $5 \mathrm{mg}$ tamoxifen was dissolved in $2 \mathrm{ml}$ dehydrated alcohol and ultrasonicated for 15 minutes. This organic phase was then slowly poured into the aqueous solution of sodium dodecyl sulfate (SDS) and polyvinyl alcohol (PVA). The solution of $1.1 \mathrm{ml} \mathrm{SDS}$ and $0.4 \mathrm{ml}$ PVA in $10 \mathrm{ml}$ de-ionized water was maintained at $35.5^{\circ} \mathrm{C}$ for $2 \mathrm{~h}$ under stirring rate of $500 \mathrm{rpm}$. The oil in water emulsion was formed after removal of alcohol under reduced pressure. The resulting aqueous suspension containing Tamoxifen was denoted as solution 1, which was then added to the Nanoparticles solution (Solution 2) by varying the concentrations of solution 1 and 2 , the Tamoxifen -loading amount may be finely tuned. The resulting mixture was then sonicated at an energy output of $50 \mathrm{~W}$ for 30 minutes to obtain a uniform solution, denoted as solution 3, which was then added drop wise to $30 \mathrm{ml}$ liquid paraffin under stirring for $12 \mathrm{~h}$. the water in oil emulsion was formed without extra emulsifier. Finally, $1 \mathrm{ml}$ of 20 wt.\% sodium citrate was added to crosslink the HSA reduced AgNps for $1 \mathrm{~h}$, and the resulting nanoparticles were purified and stored after being dried.

\section{Characterization of the nanoparticles}

The prepared Ag-NPs were characterized by X-ray diffraction (XRD), Scanning electron microcopy (SEM), energy-dispersive X-ray spectrometry (EDAX) and Fouriertransform infrared spectroscopy (FTIR). The structures of silver Nanoparticles produced were examined by XRD (XRD-6000; Shimadzu). The XRD patterns were recorded at a scan speed of $4 \%$ minute. SEM was performed using a Philips XL-30 instrument (Philips, Eindhoven, Netherlands) to study the morphology of Ag-NPs. The EDAX was carried out on a DX-700HS spectrometer. Meanwhile, the FT-IR spectra were recorded over the range of $400-4000 \mathrm{~cm}^{-1}$ using an FT-IR series 100, 1650 PerkinElmer spectrophotometer (Los Angeles, CA)

\section{Determination of drug loading and encapsulation efficiency:}

The drug loading efficacy was calculated by two ways, first based on indirect method by estimating the drug content of the supernatant and second based on direct estimation of the drug content present in the pellet obtained after centrifugation. The drug concentration in supernatant and redispersed pellets were determined by measurements of its UV absorbance at $254 \mathrm{~nm}$ using UV/visible spectroscopy and the percentage loading of drug on to nanoparticles was estimated by the following formula.

\begin{tabular}{ll}
$\begin{array}{l}\text { Loading } \\
\text { efficiency }=\end{array}$ & $\mathrm{W}_{0} \times 100 \%$ \\
$\begin{array}{l}\text { Encapsulation } \\
\text { efficiency }=\end{array}$ & $\frac{\mathrm{W}_{0}}{\mathrm{~W}_{1}} \times$ \\
\hline
\end{tabular}

Where $\mathrm{W}_{0}$ is the weight of drug enveloped in the silver nanoparticles, $\mathrm{W}$ is the weight of silver nanoparticles, and $\mathrm{W}_{1}$ is the amount of drug added in the system.

\section{In Vitro drug release study}

Release behavior of Tamoxifen from nanoparticles was investigated. Tamoxifen-loaded HSA reduced AgNPs were dispersed in PBS ( $\mathrm{pH} 7.4,5 \mathrm{ml})$ and transferred into a dialysis bag. The dialysis bag was then immersed in $95 \mathrm{ml}$ of PBS at pH 5.0, 6.0, or 7.4. The release medium was continuously agitated with a stirrer at $50 \mathrm{~g}$ and $37 \circ \mathrm{C}$. At predetermined time intervals, $2 \mathrm{ml}$ of the external medium was collected and replaced with the same fresh PBS. The amount of released Tamoxifen in the medium was then determined at $254 \mathrm{~nm}$.

\section{In Vitro Cytotoxicity Study}

The MCF-7 cells were cultured in Dulbecco's modified Eagle's medium (DMEM) supplemented with $1.5 \mathrm{~g} / \mathrm{ml}$ sodium bicarbonate, $4 \mathrm{~mm}$ glutamine and 10\% fetal bovine serum (FBS). The cultures were maintained in a humidified atmosphere with $5 \% \mathrm{CO} 2$ at $37 \circ \mathrm{C}$. Briefly, the cells were cultured in 96-well plates with different concentration $(0-$ $60 \mu \mathrm{g} / \mathrm{ml})$ of drug loaded nanoparticles with the same amount of drug for $48 \mathrm{~h}$. All the experiments are performed in triplicates.

\section{Fluorescence microscopic observation}

The MCF-7 cells were grown $\left(1 \times 10^{5}\right.$ cells/cover slip $)$ and incubated with nanoparticles at their different concentration and then they were fixed in methanol: acetic acid $(3: 1, \mathrm{v} / \mathrm{v})$. The cover slips were gently mounted on glass slides for the morphometric analysis. Morphological changes of MCF-7 cells were analyzed under fluorescence microscope at $400 \times$ magnification. Approximately $5 \mu \mathrm{l}$ of dye mixture (100 $\mathrm{mg} / \mathrm{ml}$ acridine orange (AO) and $100 \mathrm{mg} / \mathrm{ml}$ Ethidium bromide (EtBr) was mixed with $9 \mathrm{ml}$ of cell suspension $(1 \times$ $10^{5}$ cells $/ \mathrm{ml}$ ) on a clean microscopic cover slip. After incubation for 2-3 min, cells were visualized under 


\section{International Journal of Science and Research (IJSR) \\ ISSN (Online): 2319-7064 \\ Index Copernicus Value (2015): 78.96 | Impact Factor (2015): 6.391}

fluorescence microscope at 400× magnification with excitation filter at 510-590 $\mathrm{nm}$. The percentage of total apoptotic cells was determined by the following formula;

$\%$ of apoptotic cells $=$

Total number of apoptotic cells $\times 100$

Total number of normal and apoptotic cells

\section{Cell uptake efficiency of nanoparticles}

The MCF-7 cells were seeded in 96-well micro titer plate. After the cells reached $70-80 \%$ confluence, they were incubated with drug or drug loaded nanoparticles $0 \%$ and $50 \%$ nanoparticles at $5 \mu \mathrm{g} / \mathrm{ml}$ drug concentration for $1,2,3$ and $4 \mathrm{~h}$, respectively at $37 \circ \mathrm{C}$. At the designated interval, the sample wells were washed three times with $50 \mathrm{ml}$ cold PBS and then added with $100 \mathrm{ml}$ culture medium. After that, all the wells were lysed by $50 \mathrm{ml} 0.5 \%$ Triton X-100 in $0.2 \mathrm{~N}$ $\mathrm{NaOH}$. The amount of Tamoxifen in the cells was fluorometrically determined for the lysate with an excitation wavelength of $254 \mathrm{~nm}$ and an emission wavelength of 380 $\mathrm{nm}$ using a fluorescence spectrometer. The cellular uptake efficiency was expressed as the percentage of the fluorescence associated with the cells vs. that present in the positive control solution.

\section{Results and Discussion}

Human serum albumin is a most abundant plasma protein and it is widely used in Bio-nanotechnological applications. It possesses a zwitter ionic character at the isoelectric point ( $\mathrm{pH}$ 7.4) wit exposed ionic groups ( $\mathrm{C}$ and $\mathrm{N}$ Terminus) at the side chains of the globular protein, which are present in solution and are promising sites for binding cationic and anionic groups [14].The general process for synthesis of Nanomaterials in the foam matrix involves the electrostatic complexation of metal ions with oppositely charged surfactant molecules, followed by foam generation and subsequent insitu chemical reaction. HSA imparts greater flexibility by allowing the complexation of metal ions with opposite charges simultaneously [15]. In this study we prepare AgNps, by mixing HSA and Silver Nitrate solution. The formation of Ag Nanoparticles was further confirmed by using Scanning electron microcopy (SEM), X-ray diffraction (XRD), Energy-dispersive X-ray spectrometry (EDAX) and Fourier-transform infrared spectroscopy (FTIR).

Scanning Electron Microscopy was employed to visualize the size and shape of Ag-NPs. Figure 1 shows that the particles are relatively face centered cubical with the diameter of 20-30 nm. The Nanoparticles were not in direct contact even within aggregates, indicating stabilization of the Nanoparticles by HSA as capping agent.

Figure 2 shows XRD patterns for Ag-NPs synthesized using HSA. The XRD pattern indicated that the structure of AgNPs is face centered cubic [16]. In addition, all the Ag-NPs had a similar diffraction profile, and XRD peaks at $2 \theta$ of $34^{0}, 49.1^{0}, 58.9^{0}$ and $71.4^{0}$ could be attributed to the 111 , 200, 220 and 311 crystallographic planes of the facecentered cubic silver crystals respectively [17]. The XRD pattern thus clearly illustrated that the Ag-NPs formed in this study were crystalline in nature. The main crystalline phase was silver, and there were no obvious other phases as impurities were found in the XRD patterns. The average particle size of Ag-NPs calculated using the Debye-Scherrer equation

$$
\mathrm{n}=\quad \frac{\kappa \lambda}{\beta \cos \theta}
$$

Where $\mathrm{K}$ is the Scherrer constant with value from 0.9 to 1 (shape factor), where $\lambda$ is the X-ray wavelength (1.5418 $\AA$ ), $\beta_{1 / 2}$ is the width of the XRD peak at half-height and $\theta$ is the Bragg angle. From the Scherrer equation, the average crystallite size of Ag-NPs for the sample at 24 hours of stirring are found to be $20-30 \mathrm{~nm}$ in size.

Figure 3 shows the clear elemental composition profile of the synthesized Ag-NPs. The intense signal at $3 \mathrm{keV}$ strongly suggests that Ag was the major element of these NPs, as it has optical absorption in this range due to the surface Plasmon resonance [18]. The other signals (carbon and oxygen) indicate the presence of tuber extract, which corresponds to the biomolecules that were capping over the Ag-NPs.

Tamoxifen loaded Ag-Nps with high drug payload was successfully prepared and characterized by FTIR spectra. The FTIR spectra of Ag-Nps alone (fig 4), Tamoxifen alone (fig 5 (a)) and Tamoxifen loaded Ag-Nps (fig 5(b)) are shown. The three characterization peaks at 3417.86 $\mathrm{cm}^{-1}$ (- OH), $1510.26 \mathrm{~cm}^{-1}$ (C-O-C) and $1060.85 \mathrm{~cm}^{-1}(\mathrm{~N}-\mathrm{H})$ were taken into account. In comparison, the peak at 3417.86 $\mathrm{cm}^{-1}$ of Tamoxifen loaded $\mathrm{Ag}-\mathrm{Nps}$ was much wider than Tamoxifen, indicating the stretching of hydrogen bonds. The peak at $1658.78 \mathrm{~cm}^{-1}$ noticed in Tamoxifen was found to be shifted in Tamoxifen loaded Ag-Nps with a peak at 1653.00 $\mathrm{cm}^{-1}$. From the dissolution point of view, the salvation of $\mathrm{Ag}-\mathrm{Nps}$ is related to the protonation of free amine groups and breakdown of strong intra- and inters- molecular hydrogen bonding. The $\mathrm{H}-$ bonding established through $\mathrm{NH}_{2}$ linkage makes the molecule behave as a resonating structure owing to unshared electron pairs that are less available for protonation. In addition, nitro groups withdraw electrons, making them less accessible at the secondary amide and primary amide groups during interaction. It is evident from the graph that there is a possible interaction between Tamoxifen and Ag-Nps. A shift in the peak of Tamoxifen loaded Ag-Nps indicates the interaction of AgNps with Tamoxifen. The change indicates encapsulation of Tamoxifen to form Ag-Nps successfully.

The drug loading on Ag-Nps is done and the amount of drug loaded is shown in the table 1 . The result clearly indicates that the amount of drug loading depends on the ratio of drug and carrier. The drug loading percentage increases when the amount of Ag-Nps is increased and it decreases when the amount of drug is increased for a given amount of Ag-Nps. The amount of drug loaded per mg of Ag-Nps has been calculated. The amount of drug loaded per mg of Ag-Nps decreases with increase in the Ag-Nps and it increases with increase in the amount of drug. At a ratio of $2: 1$, the maximum amount of drug is loaded per $\mathrm{mg}$ of Ag-Nps. When the amount of drug is increased, there is no further increase in the amount of drug loaded per mg of

\section{Volume 6 Issue 1, January 2017}




\section{International Journal of Science and Research (IJSR) \\ ISSN (Online): 2319-7064}

Index Copernicus Value (2015): 78.96 | Impact Factor (2015): 6.391

Ag-Nps. $0.7 \mathrm{mg}$ of Tamoxifen is the maximum of the drug loaded per mg of Ag-Nps.

As shown in the Figure 6, release of drug molecules depended on $\mathrm{pH}$ of the medium and release time. Drug release at $\mathrm{pH} 7.4$ was slow and sustained with release ratio at about $16 \pm 0.58 \%$ within $48 \mathrm{~h}$. However, Tamoxifen release rate was much faster at lower $\mathrm{pH}$, with approximately $32 \pm 0.58 \%(\mathrm{pH} 6.0)$ and $53 \pm 0.63 \%(\mathrm{pH}$ 4.0) of the drug released within $48 \mathrm{~h}$. Protonation of the drug occurred at lower $\mathrm{pH}$, which released chemisorbed drug molecules in to the medium. Furthermore, the surface charge of Ag-Nps turned positive at lower $\mathrm{pH}$, which blunted the electrostatic interaction of drug and Ag-Nps and facilitated the drug release process. These results demonstrate $\mathrm{pH}$-triggered drug release behavior from the novel Tamoxifen Delivery System.

It may be hypothesized that most of the drug will remain in the carrier for a considerable time period at normal

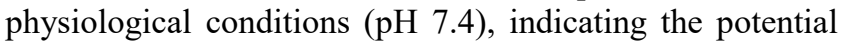
for prolonged drug retention time in blood circulation and thereby greatly reducing the side effects of normal tissues. On the other hand, once drug-loaded Ag-Nps are taken up by the tumor cells via endocytotic process, a faster release may occur at lower $\mathrm{pH}$ i.e., surrounding the tumor site or inside the endosome and lysosme of tumor cells, leading to significant improvement in cancer treatment efficacy [19].

To further explore the anti cancer efficiency of the AgNps synthesised using HSA, MCF-7 cells were culture with drug at different concentrations $(0-60 \mu \mathrm{g} / \mathrm{ml})$ and drug loaded nanoparticles with equivalent drug concentration for $48 \mathrm{~h}$. Cytotoxic results were estimated by MTT assay (Figure 7). The MCF -7 cells treated by drug loaded HSA reduced AgNps showed decreases viability compared with drug alone $(* p<0.05)$. It is apparent that drug and even more effective drug loaded HSA reduced AgNps could arrest the growth of cancer cells and cause more significant morphological changes, indicating an increased probability in cell death.

The fluorescent microscopy study on MCF-7 breast cancer cells treated with different concentrations of HSA reduced AgNps loaded with drug was conducted using $\mathrm{AO} / \mathrm{EtBr}$ staining in order to evaluate the influence of drug loaded nanoparticles on MCF-7 cells. Figure 8 shows the images of normal and Tamoxifen-loaded HSA reduced AgNps treated MCF-7 cells. In Ao/EtBr staining cells observed as orange color are apoptotic and necrotic cells were observed as red color fluorescence due to their loss of membrane integrity [20].

The cellular uptake efficiency of tamoxifen loaded HSA reduced AgNps was compared to the tamoxifen alone after 1, 2, 3 and $4 \mathrm{~h}$ in cell culture (Figure 9). Tamoxifen loaded HSA reduced AgNps exhibited enhanced cellular uptake $\left({ }^{*} p<0.05\right)$ for the MCF-7 cells after $1,2,3$ and 4 h culture, respectively, compared with tamoxifen alone. It can be seen that Tamoxifen loaded HSA reduced AgNps demonstrated much higher cellular uptake efficiency than the drug.

\section{Conclusion}

In the present study, Tamoxifen loaded HSA reduced AgNPs were formulated and $\mathrm{pH}$-responsive drug release study revealed that the drug release was significantly accelerated by decreasing $\mathrm{pH}$ from 7.4 to 4.0 . This mechanism has a particular interest in cancer therapy due to the acidic extracellular tumor environment in the cancer cells. The blank HSA reduced AgNPs had almost no cytotoxicity besides, the inhibiting rate of drug loaded HSA reduced AgNPs to MCF-7 breast cancer cells tended to increase with increase in the concentration of drug. All these characteristics demonstrate that the novel $\mathrm{pH}$-responsive drug delivery system based on HSA reduced AgNPs for Tamoxifen is a promising strategy for cancer therapy.

\section{Acknowledgements}

We gratefully acknowledge the University Grants Commission, Hyderabad, for sanctioning this minor research project and providing financial assistance. My heartfelt thanks to Sri Kaliswari College, Sivakasi for helping us to carry out as a part of our research work successfully. I am thankful to K.S.G College of Arts and Science, Coimbatore for encouraging me and providing laboratory facilities.

\section{References}

[1] des Rieux A, Fievez V, Garinot M, Schneider YJ, Préat V. Nanoparticles as potential oral delivery systems of proteins and vaccines: a mechanistic approach. Journal of controlled release. 2006 Nov 10;116(1):1-27.

[2] Shenoy DB, Amiji MM. Poly (ethylene oxide)-modified poly ( $\varepsilon$-caprolactone) nanoparticles for targeted delivery of tamoxifen in breast cancer. International journal of pharmaceutics. 2005 Apr 11;293(1):261-70.

[3] Glen A. The impact of nanotechnology in drug delivery: Global developments. Market Anal. Future Prospects. 2005.

[4] Leroux JC, Allémann E, De Jaeghere F, Doelker E, Gurny R. Biodegradable nanoparticles-from sustained release formulations to improved site specific drug delivery. Journal of Controlled Release. 1996 May 1;39(2-3):339-50.

[5] Alexis F, Pridgen E, Molnar LK, Farokhzad OC. Factors affecting the clearance and biodistribution of polymeric nanoparticles. Molecular pharmaceutics. 2008 Aug 4;5(4):505-15.

[6] Cheng Q, Feng J, Chen J, Zhu X, Li F. Brain transport of neurotoxin-I with PLA nanoparticles through intranasal administration in rats: a microdialysis study. Biopharmaceutics \& drug disposition. 2008 Nov $1 ; 29(8): 431-9$.

[7] Singal PK, Iliskovic N. Doxorubicin-induced cardiomyopathy. New England Journal of Medicine. 1998 Sep 24;339(13):900-5.

[8] Singal P, Li T, Kumar D, Danelisen I, Iliskovic N. Adriamycin-induced heart failure: mechanisms and modulation. Molecular and cellular biochemistry. 2000 Apr 1;207(1):77-86.

[9] Seigneuric R, Markey L, SA Nuyten D, Dubernet C, TA Evelo C, Finot E, Garrido C. From nanotechnology to nanomedicine: applications to cancer research. Current Molecular Medicine. 2010 Oct 1;10(7):640-52.

\section{Volume 6 Issue 1, January 2017




\section{International Journal of Science and Research (IJSR) \\ ISSN (Online): 2319-7064 \\ Index Copernicus Value (2015): 78.96 | Impact Factor (2015): 6.391}

[10] Kratz F. Albumin as a drug carrier: design of prodrugs, drug conjugates and nanoparticles. Journal of controlled release. 2008 Dec 18;132(3):171-83.

[11] Son YJ, Jang JS, Cho YW, Chung H, Park RW, Kwon IC, Kim IS, Park JY, Seo SB, Park CR, Jeong SY. Biodistribution and anti-tumor efficacy of doxorubicin loaded glycol-chitosan nanoaggregates by EPR effect. Journal of Controlled Release. 2003 Aug 28;91(1):13545.

[12] Mody VV, Siwale R, Singh A, Mody HR. Introduction to metallic nanoparticles. Journal of Pharmacy and Bioallied Sciences. 2010 Oct 1;2(4):282.

[13] Sevilla P, De Llanos R, Domingo C, Sánchez-Cortés S, Garcia-Ramos JV. SERS+ MEF of the anti-tumoral drug emodin adsorbed on silver nanoparticles. InBiOS 2010 Feb 11 (pp. 757714-757714). International Society for Optics and Photonics.

[14]Huang Xl, Catignani Gl, Swaisgood He. Micro-scale Method for Determining Foaming Properties of Protein. Journal of food science. 1997 Sep 1;62(5):1028-60.

[15] Singh AV, Bandgar BM, Kasture M, Prasad BL, Sastry M. Synthesis of gold, silver and their alloy nanoparticles using bovine serum albumin as foaming and stabilizing agent. Journal of Materials Chemistry. 2005;15(48):5115-21.
[16] Ahmad A, Mukherjee P, Senapati S, Mandal D, Khan MI, Kumar R, Sastry M. Extracellular biosynthesis of silver nanoparticles using the fungus Fusarium oxysporum. Colloids and surfaces B: Biointerfaces. 2003 May 1;28(4):313-8.

[17] Ahmad T, Wani IA, Manzoor N, Ahmed J, Asiri AM. Biosynthesis, structural characterization and antimicrobial activity of gold and silver nanoparticles. Colloids and Surfaces B: Biointerfaces. 2013 Jul 1;107:227-34.

[18] Shameli K, Ahmad MB, Jazayeri SD, Shabanzadeh P, Sangpour P, Jahangirian H, Gharayebi Y. Investigation of antibacterial properties silver nanoparticles prepared via green method. Chemistry Central Journal. 2012 Jul $27 ; 6(1): 1$

[19]Zhang H. Daunorubicin-TiO. International journal of nanomedicine. 2012;7:235-42.

[20] Vivek R, Thangam R, Muthuchelian K, Gunasekaran P, Kaveri K, Kannan S. Green biosynthesis of silver nanoparticles from Annona squamosa leaf extract and its in vitro cytotoxic effect on MCF-7 cells. Process Biochemistry. 2012 Dec 31;47(12):2405-10.

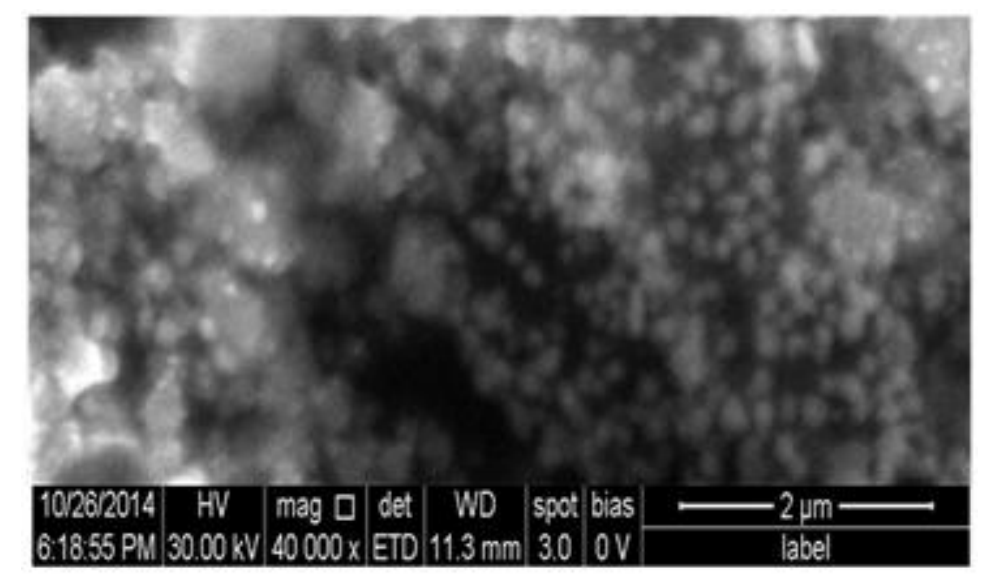

Figure1: Scanning Electron Microscopy image of HSA reduced Ag-NPs which are face centered cubical in shape

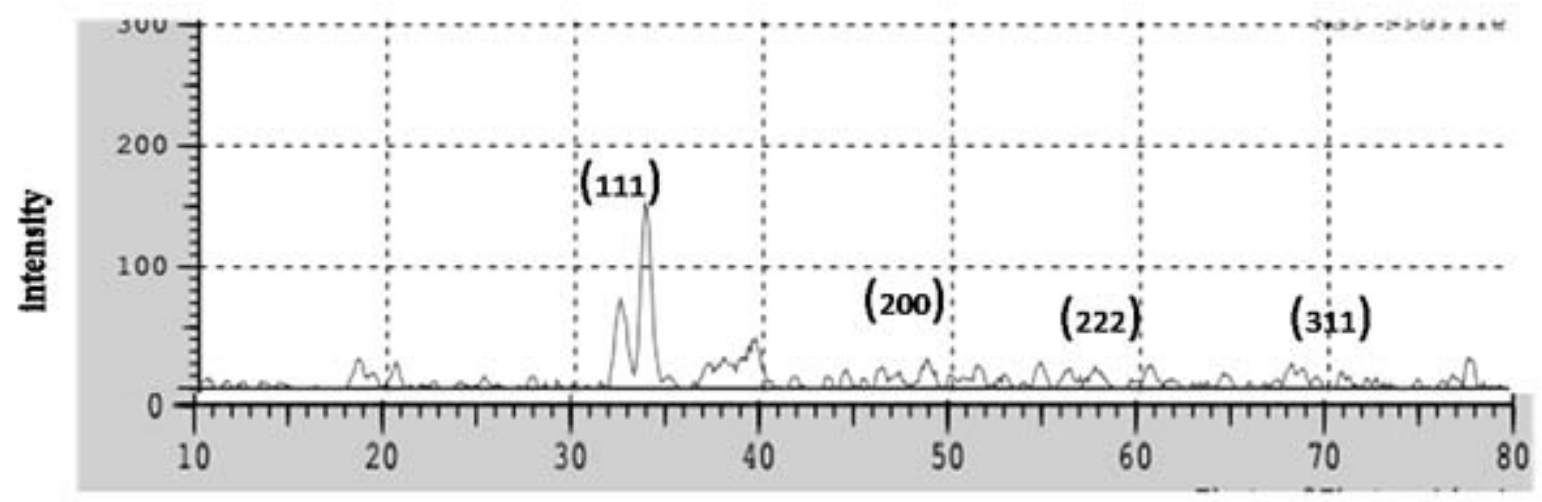

20 degree

Figure 2: X-ray diffraction pattern of Ag-NPs synthesized using HSA. The diffractions at $34^{0}, 49.1^{0}, 58.9^{0}$ and $71.4^{0}$ can be indexed to 111, 200, 220 and 311 planes of the face-centered cubic Ag-NPs, respectively 


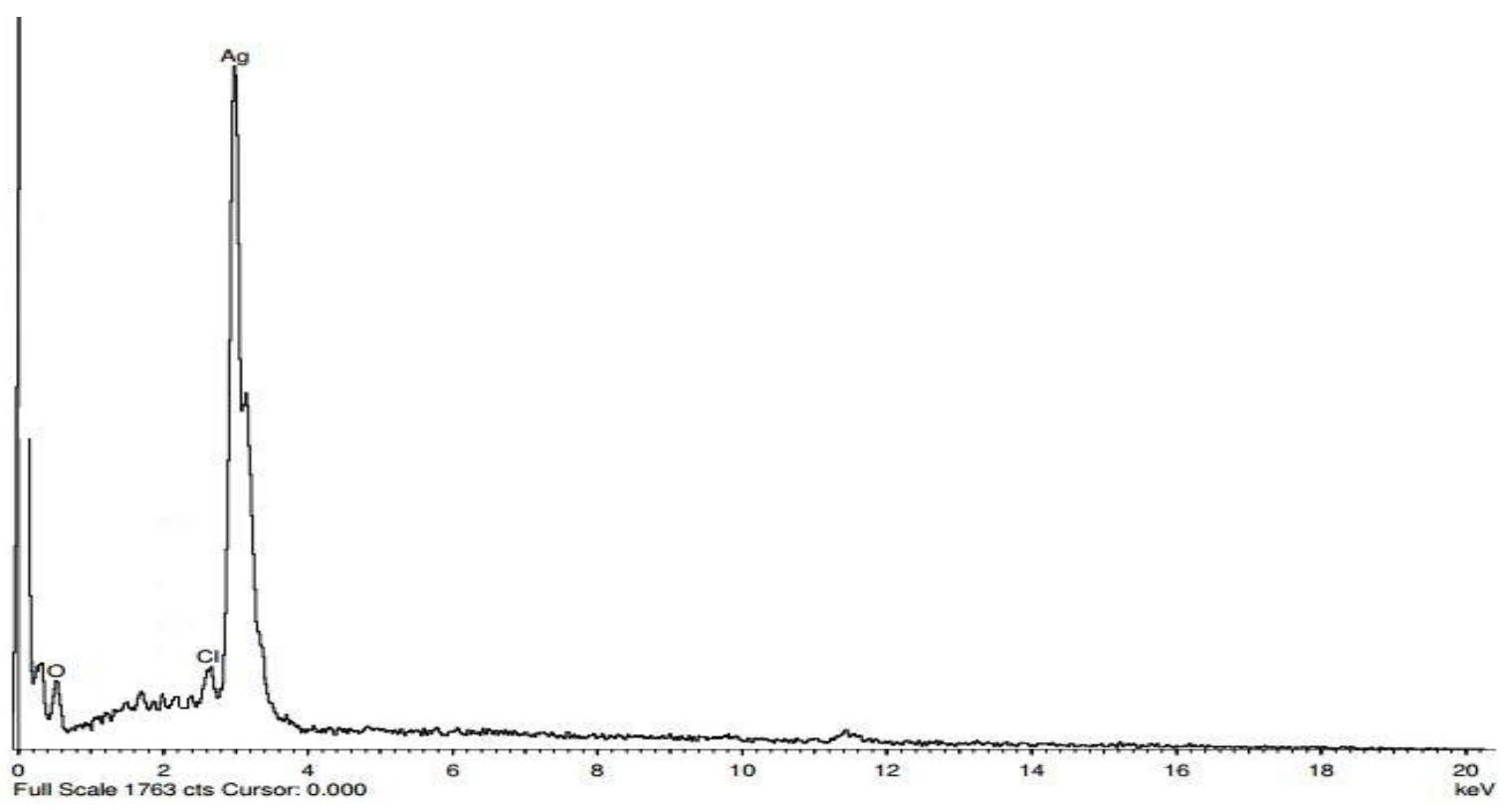

Figure 3: Energy dispersive X-ray fluorescence spectrometry spectra of HSA reduced Ag-NPs

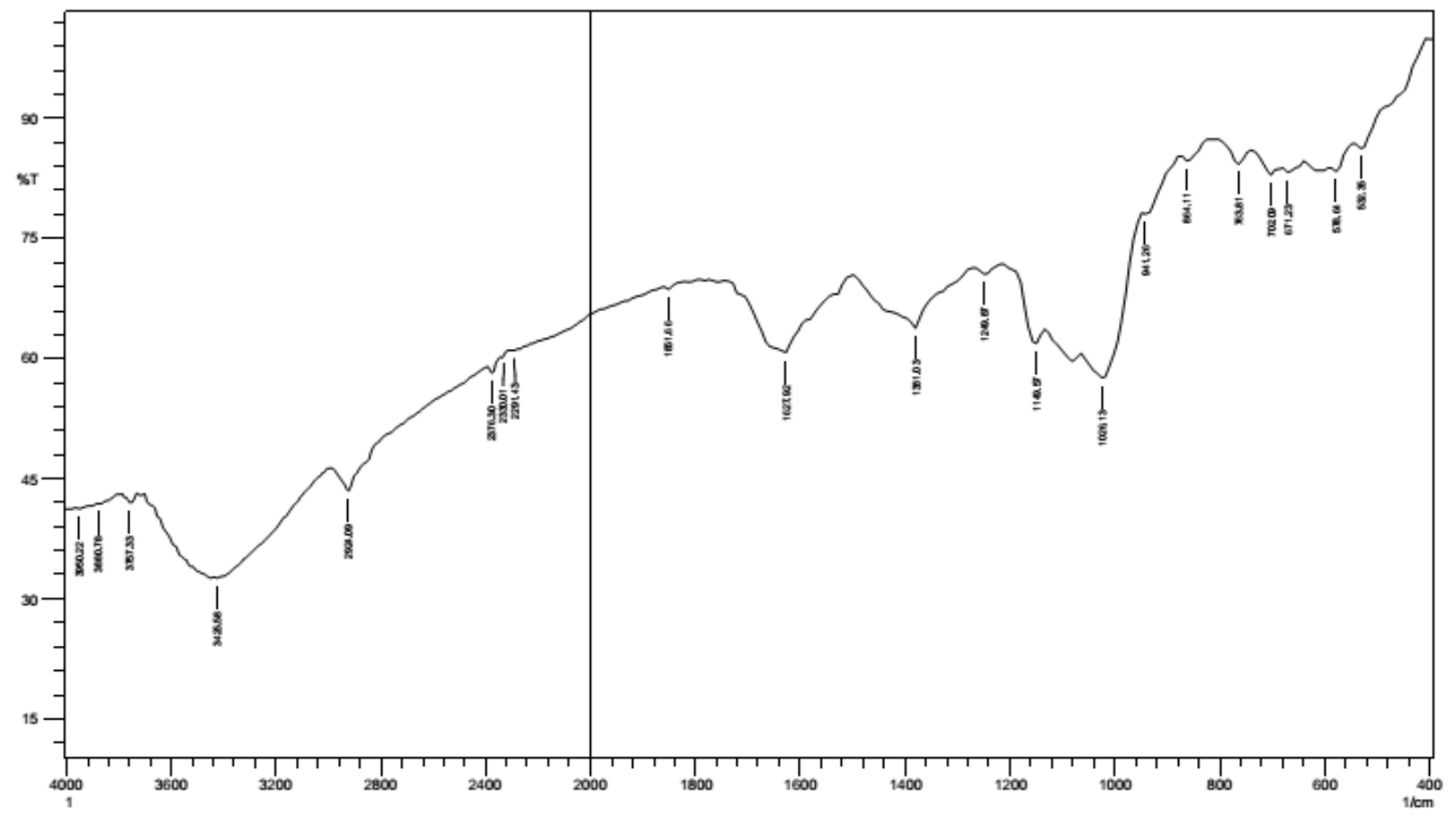

Figure 4: Fourier Transform Infra red spectra for Ag-NPs synthesized using HAS 


\section{International Journal of Science and Research (IJSR)}

ISSN (Online): 2319-7064

Index Copernicus Value (2015): 78.96 | Impact Factor (2015): 6.391

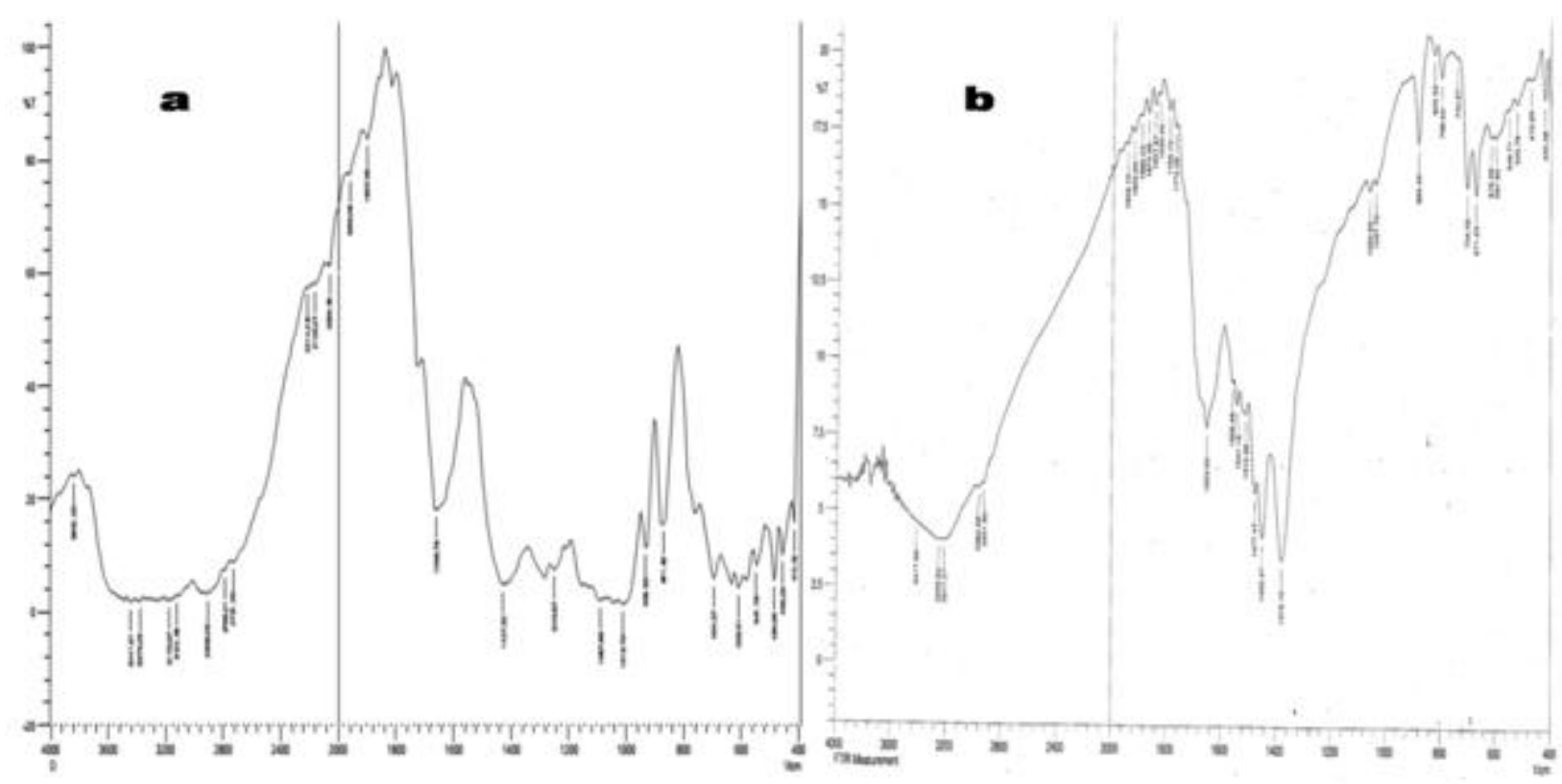

Figure 5: (a) Fourier Transform Infra red spectra for Tamoxifen. (b) Fourier Transform Infra red spectra of Tamoxifen loaded Ag-Nps

Table 1: Drug loading in percentage for different ratios of Tamoxifen and Ag-Nps

\begin{tabular}{|c|c|c|c|}
\hline S.No & $\begin{array}{c}\text { Tamoxifen: } \\
\text { Ag-Nps }\end{array}$ & $\begin{array}{c}\text { Drug } \\
\text { Loading (\%) }\end{array}$ & $\begin{array}{c}\text { mg of Tamoxifen / } \\
\text { mg of Ag-Nps }\end{array}$ \\
\hline $\mathbf{1 .}$ & $1: 1$ & 51.6 & 0.51 \\
\hline $\mathbf{2 .}$ & $1: 2$ & 62.14 & 0.33 \\
\hline $\mathbf{3 .}$ & $1: 4$ & 77.35 & 0.31 \\
\hline $\mathbf{4 .}$ & $2: 1$ & 30.5 & 0.70 \\
\hline $\mathbf{5 .}$ & $4: 1$ & 10.5 & 0.70 \\
\hline
\end{tabular}

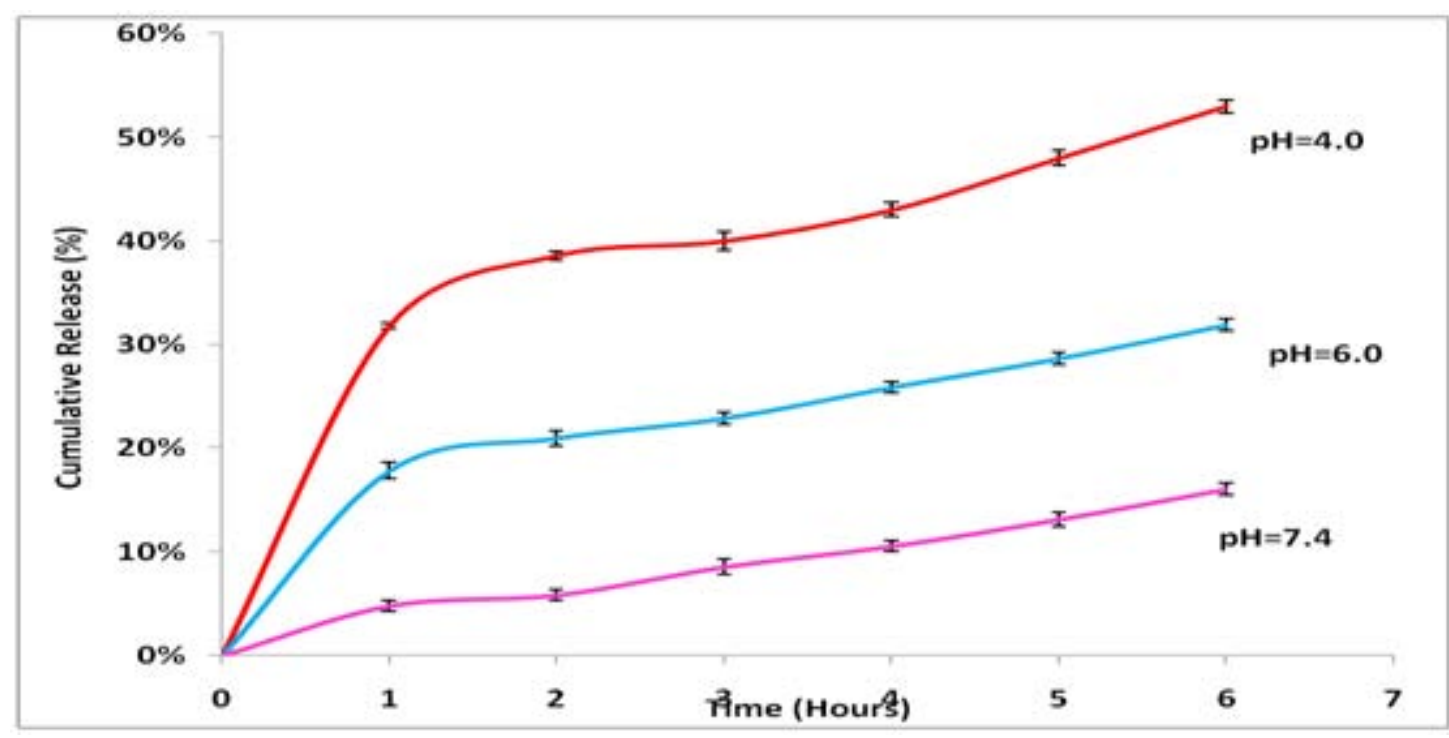

Figure 6: In vitro drug release profiles from Ag-Nps at neutral condition ( $\mathrm{pH} 7.4)$ and acidic condition $(\mathrm{pH} 6.0$ and $\mathrm{pH} 4.0)$ at $37^{\circ} \mathrm{C}$. Each point represents the mean $\pm \mathrm{SD}$. 


\section{International Journal of Science and Research (IJSR) \\ ISSN (Online): 2319-7064}

Index Copernicus Value (2015): 78.96 | Impact Factor (2015): 6.391

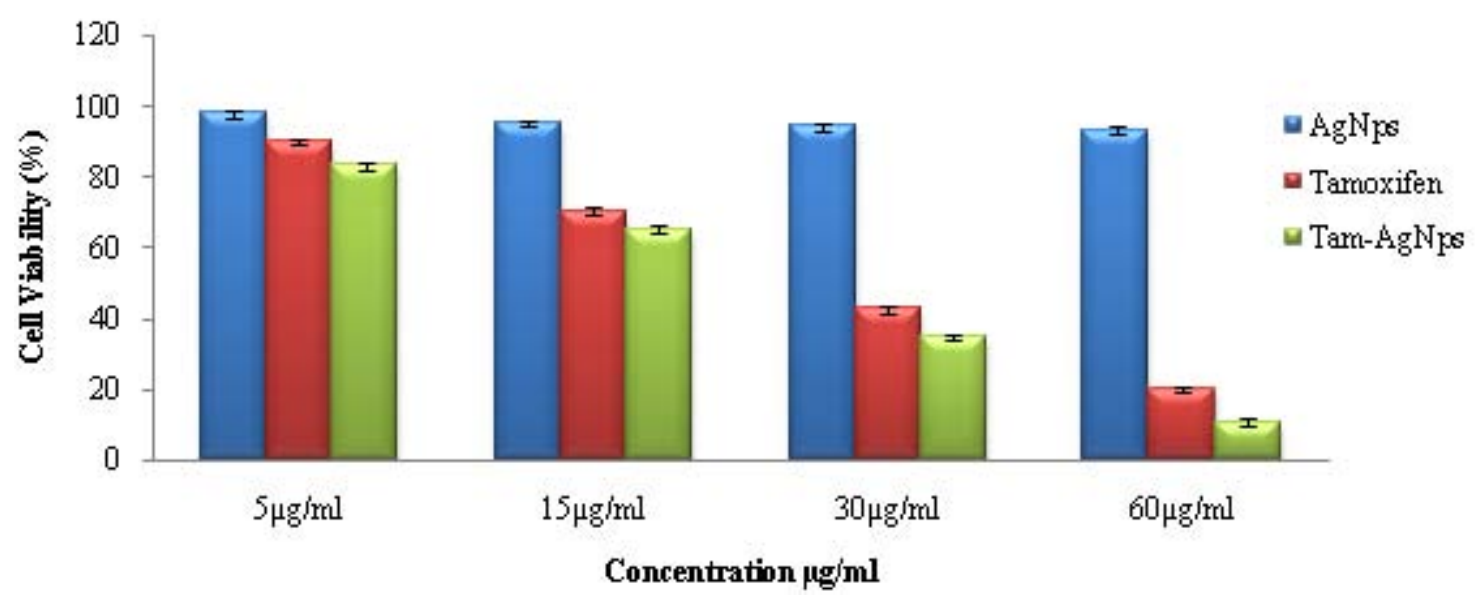

Figure 7: MCF-7 cells were treated with AgNps, tamoxifen and Tamoxifen Loaded AgNps for 48 h and cell viability was determined b colorimetric MTT assay. Data represent mean $\pm \mathrm{SD}$.

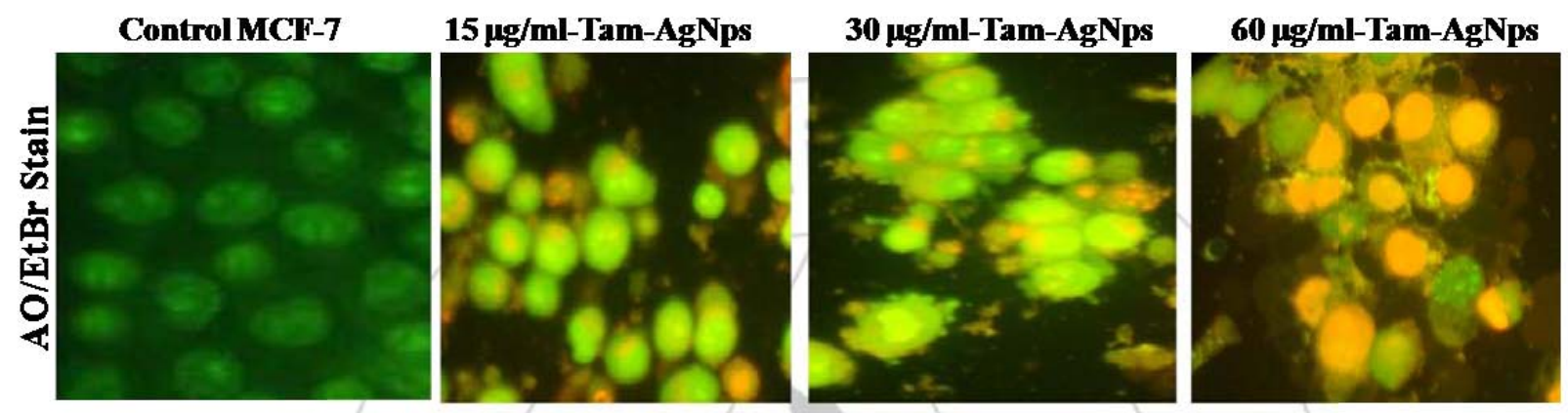

Figure 8: Fluorescent microscopic image of MCF-7 cells treated with AgNps loading Tamoxifen as a drug delivery system by Ao/EtBr Staining

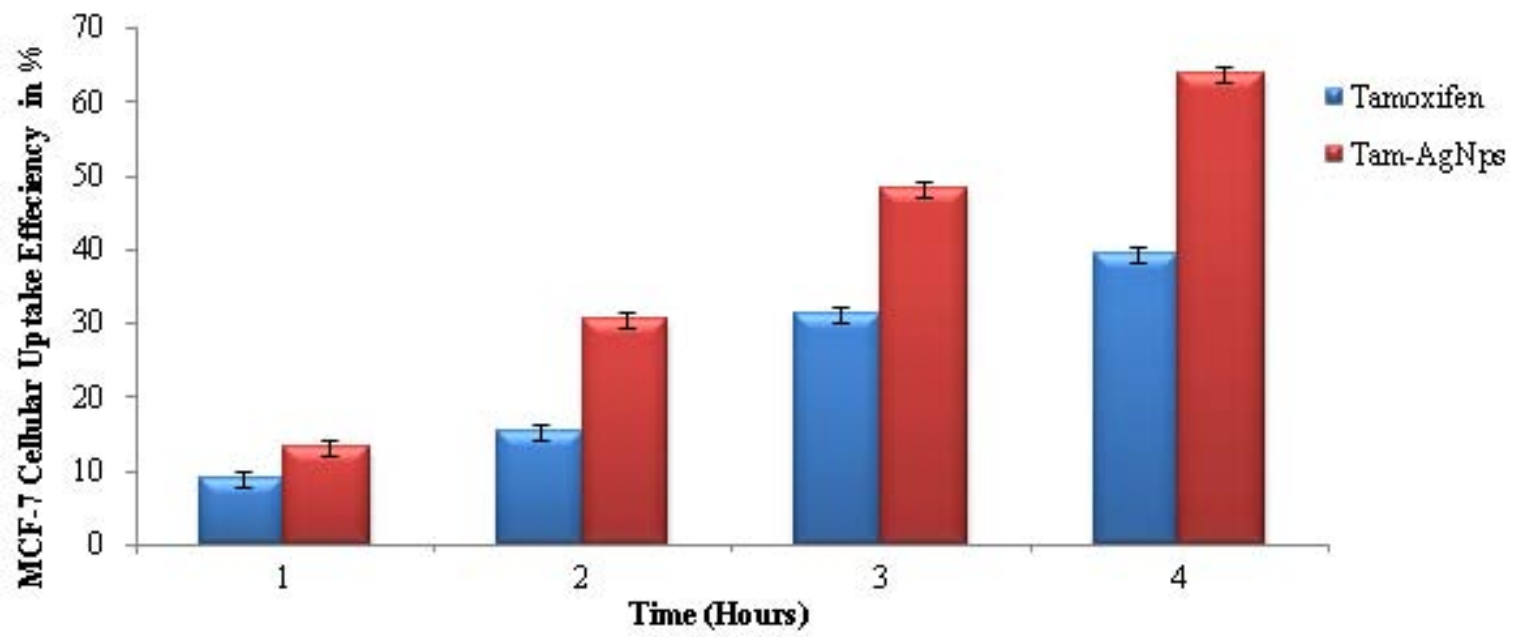

Figure 9: Time dependent cellular uptake efficiency of Tamoxifen loaded HSA reduced AgNps by MCF-7 cells after 1.0, 2.0, 3.0 and $4.0 \mathrm{~h}$ of incubation. Data represent mean $\pm \mathrm{SD}$.

\section{Author Profile}

V. Pradeepa is in Department of Biotechnology, K.S.G College of Arts and Science, Coimbatore-641

015, Tamil Nadu, India 